\title{
Age-Dependent Maintenance of Motor Control and Corticostriatal Innervation by Death Receptor 3
}

\author{
Jason Peter Twohig, ${ }^{1}$ Malcolm I. Roberts, ${ }^{3}$ Nuria Gavalda, ${ }^{4}$ Emma L. Rees-Taylor, ${ }^{1}$ Albert Giralt, ${ }^{6}$ Debbie Adams, ${ }^{2}$ \\ Simon P. Brooks, ${ }^{4}$ Melanie J. Bull, ${ }^{1}$ Claudia J. Calder, ${ }^{1}$ Simone Cuff, ${ }^{1}$ Audrey A. Yong, ${ }^{5}$ Jordi Alberch, ${ }^{6}$ Alun Davies, ${ }^{4}$ \\ Stephen B. Dunnett, ${ }^{4}$ Aviva M. Tolkovsky, ${ }^{3}$ and Eddie C. Y. Wang ${ }^{1}$ \\ ${ }^{1}$ Department of Infection, Immunity \& Biochemistry and ${ }^{2}$ Biomedical Services Unit, School of Medicine, Cardiff University, Cardiff CF14 4XN, Wales, \\ United Kingdom, ${ }^{3}$ Department of Biochemistry, University of Cambridge, Cambridge CB2 1QW, United Kingdom, ${ }^{4}$ BIOSI 3, School of Biosciences, Cardiff \\ University, Cardiff CF10 3US, Wales, United Kingdom, ${ }^{5}$ Department of Radiology, Cardiff \& Vale NHS Trust, University Hospital of Wales, Cardiff CF14 \\ 4XN, Wales, United Kingdom, and ${ }^{6}$ Department of Cell Biology, Immunology \& Neuroscience, Faculty of Medicine, Institut d'investigacions Biomediques \\ August Pi i Sunyer, Centro de Investigacion Biomedica en Redsobre Enfrmedades Neurodegenerativas, University of Barcelona, 08036 Barcelona, Spain
}

Death receptor 3 is a proinflammatory member of the immunomodulatory tumor necrosis factor receptor superfamily, which has been implicated in several inflammatory diseases such as arthritis and inflammatory bowel disease. Intriguingly however, constitutive DR3 expression has been detected in the brains of mice, rats, and humans, although its neurological function remains unknown. By mapping the normal brain expression pattern of DR3, we found that DR3 is expressed specifically by cells of the neuron lineage in a developmentally regulated and region-specific pattern. Behavioral studies on DR3-deficient $\left(\mathrm{DR} 3{ }^{\mathrm{ko}}\right)$ mice showed that constitutive neuronal DR3 expression was required for stable motor control function in the aging adult. DR $3^{\mathrm{ko}}$ mice progressively developed behavioral defects characterized by altered gait, dyskinesia, and hyperactivity, which were associated with elevated dopamine and lower serotonin levels in the striatum. Importantly, retrograde tracing showed that absence of DR3 expression led to the loss of corticostriatal innervation without significant neuronal loss in aged DR $3{ }^{\mathrm{ko}}$ mice. These studies indicate that DR3 plays a key nonredundant role in the retention of normal motor control function during aging in mice and implicate DR3 in progressive neurological disease.

\section{Introduction}

The process of aging in the brain is complex and characterized by progressive alterations to neural signaling pathways affecting behavior (O'Sullivan et al., 2001; Andrews-Hanna et al., 2007). Agerelated declines in motor control function appear to reflect environmental and genetic components altering neuron lifespan and function (Mattson et al., 2002; Heuninckx et al., 2005; Yankner et al., 2008). Continued motor control function and spatial awareness are critically reliant upon neuronal signaling between the cortex, which translates sensory input, and the striatum (Goldman-Rakic, 1987; Rakic, 1988), which mediates motor and cognitive processes (Goldman-Rakic, 1987; Dubé et al., 1988; Rakic, 1988; Albin et al., 1989; Smith et al., 1994; Groenewegen, 2003; Grahn et al., 2008). The neurotransmitter dopamine plays a primary role in the conduction of all motor control signaling within the striatum (Di Matteo et al., 2008; Palmiter, 2008; Yao et al., 2008). The processes that govern

\footnotetext{
Received April 3, 2009; revised Sept. 10, 2009; accepted Sept. 18, 2009.

This work was supported by Medical Research Council Career Establishment (G0300180) and Collaboration (G0500617) Grants awarded to E.C.Y.W. M.I.R. was supported by a Biotechnology and Biological Sciences Research Council CASE studentship (C/05060) in collaboration with Glaxo Smith Kline (GSK). A.M.T. was supported by a Wellcome Trust programme grant (064232). We thank Peter Maycox and Isabel Benzel at GSK for helpful discussion and support.

The authors declare no competing financial interests.

Correspondence should be addressed to Eddie C.Y.Wang at the above address. E-mail:wangec@cf.ac.uk. DOI:10.1523/JNEUROSCI.1928-09.2010

Copyright $\odot 2010$ the authors $\quad 0270-6474 / 10 / 303782-11 \$ 15.00 / 0$
}

the homeostatic maintenance of these neural pathways following their formation in the aging adult are poorly understood.

Death receptor 3 (DR3, Wsl-1, Apo3, LARD, TRAMP, TNFRSF25, TR3) (Chinnaiyan et al., 1996; Kitson et al., 1996; Marsters et al., 1996; Bodmer et al., 1997; Screaton et al., 1997) is a member of the tumor necrosis factor receptor superfamily (TNFRSF), a group of structurally related immunomodulatory cytokine receptors capable of triggering NF- $\kappa \mathrm{B}$ induction and/or caspase activation (Ashkenazi and Dixit, 1998; Mackay and Kalled, 2002). DR3 along with its ligand TNF-like factor 1A (TL1A) has been described as proinflammatory in several murine disease models (Al-Lamki et al., 2003; Bamias et al., 2006; Bull et al., 2008; Fang et al., 2008; Meylan et al., 2008; Pappu et al., 2008; Takedatsu et al., 2008) and in chronic human diseases such as inflammatory bowel disease and rheumatoid arthritis (Osawa et al., 2004; Papadakis et al., 2005; Bamias et al., 2006; Borysenko et al., 2006; Cassatella et al., 2007). In the brain, increased DR3 expression has been reported in ischemic rats (Harrison et al., 2000) and human Alzheimer' disease (Newman et al., 2000), suggesting this receptor contributes to neuropathology. Intriguingly however, endogenous DR3 expression is also observed in the brain of normal mice, rats, and humans (Marsters et al., 1996; Wang et al., 2001b; O'Keeffe et al., 2008). Furthermore, such basal expression may be neurologically important as some TNFRSF members appear to facilitate normal neuronal differentiation and survival (Kojima et al., 2000; Nieoullon and Coquerel, 2003; Graybiel, 2005; Ishiguro et al., 2007; O’Keeffe et al., 2008). 
Collectively, these observations suggest basal DR3 brain expression may play an important role in normal neuronal function.

In this study, we addressed the physiological role of DR3 in the adult brain by examining the behavior of DR $3^{\text {ko }}$ mice during aging. We report that adult DR ${ }^{\mathrm{ko}}$ mice spontaneously develop severe behavioral defects characterized by a progressive decline in higher motor control functions with advancing age. Importantly, adult neuronal DR3 expression was found to be critical for continued maintenance of striatal neurotransmitter expression and for stable neuronal contact between the cortex and the striatum.

\section{Materials and Methods}

Mice. DR $3^{\mathrm{ko}}$ mice on a C57BL/6 background were previously generated at, and colony-founding animals supplied by, Cancer Research UK (Wang et al., 2001a). All United Kingdom (UK)-based animal experiments were subject to local ethical review and conducted according to personal, project, and institutional licenses under the UK Animals (Scientific Procedures) Act 1986. For experiments performed in Spain, animal-related procedures were in accordance with the National Institutes of Health guidelines for the care and use of laboratory animals and approved by the local animal care committee of the Universitat de Barcelona and by the Generalitat (Autonomous Government) of Catalonia.

Histological analysis. Tissue preparation, tyrosine hydroxylase (TH) and NeuN immunohistochemistry on free-floating sections, and subsequent morphometry were performed as described previously (Kelly et al., 2007). Brain region volume and cell number were based on NeuN/TH staining and determined using the Olympus CAST grid stereology system on a 1:12 series using previously described methods. At high magnification, brain region volume, neuron number, and the density of TH immunostaining were measured on four anatomically matched sections per animal using the $\times 40$ objective (Leica DMRB microscope, Leica Microsystems) and Scion image system.

Immunohistochemical detection and colocalization of NeuN, GFAP, and $\beta$-Gal in DR $3^{\text {het }}$ and DR $3^{\text {ko }}$ mice. Indirect fluorescent immunocytochemistry was performed using standard protocols with primary antibodies directed against neuronal nuclei (NeuN, PharMingen), $\beta$-galactosidase ( $\beta$-Gal, Millipore Bioscience Research Reagents), and glial fibrillary acidic protein (GFAP, DAKO). Sections were counterstained with Hoechst 33342 (2 $\mu \mathrm{g} / \mathrm{ml}$; Sigma) to label nuclei before visualization by confocal microscopy on an Olympus IX70 microscope linked into an Ultraview system (Perkin and Elmer).

Brain mapping of $\beta$-Gal expression in DR $3^{\text {het }}$ and $D R 3^{k o}$ mice. Mice were generated by replacement of the DR3 gene with a cassette including an internal ribosome entry site (IRES) and lacZ poly(A), allowing visualization using X-gal staining. Brains from DR3 ${ }^{\text {het }}$ and DR $3^{\text {ko }}$ mice were removed, flash frozen in liquid nitrogen $\left(\mathrm{LN}_{2}\right)$, coronally sectioned at 10 $\mu \mathrm{m}$ thickness, and stored at $-80^{\circ} \mathrm{C}$. Whole mouse brains being assayed for $\beta$-Gal were removed, fixed in $4 \%$ PFA, and then washed extensively in PBS. Sections being assayed for $\beta$-Gal were prepared as described above, immersed in X-gal staining solution for $18-24 \mathrm{~h}$ at $37^{\circ} \mathrm{C}$, counterstained with Nuclear Fast Red (Vector Laboratories), and hard mounted using standard techniques. Images were taken using a Nikon light microscope, Kodak EPY-64T color slide film, or a Nikon-based digital camera imaging system.

Reverse transcriptase-PCR. DR3 and TL1A expression in the brains of 8 - to 12 -week-old mice was examined by reverse transcriptase (RT)PCR. Brains from 8- to 12-week-old mice were microdissected on ice into the hippocampus, basal ganglia, cortex, cerebellum, dentate gyrus, and colliculi. Total RNA was extracted from tissues or cultured cells using RNeasy (Qiagen) and cDNA prepared using Superscript II (Invitrogen) according to the manufacturer's instructions. PCR was performed according to the following cycle preceded with Taq activation for $15 \mathrm{~min}$ at $95^{\circ} \mathrm{C}$ : step $1,94^{\circ} \mathrm{C}$ for $45 \mathrm{~s}$, an annealing step (temperature dependent upon primers) for $30 \mathrm{~s}$, and $72^{\circ} \mathrm{C}$ for $45 \mathrm{~s}$. The reaction was terminated by $10 \mathrm{~min}$ at $72^{\circ} \mathrm{C}$ and then kept at $4^{\circ} \mathrm{C}$ until required. PCR primers, annealing temperature, and expected product size for the amplification of TNFRSF members and TL1A are shown in supplemental Table 1 (available at www.jneurosci.org as supplemental material). The amount of
cDNA in each PCR was assessed by additionally amplifying a fragment of the GAPDH cDNA. Reaction products were resolved on a $1.2 \%$ agarose gel and stained with ethidium bromide before UV visualization. Band intensities were measured using Labworks analysis software.

Gait, balance, and open-field analysis. Gait and balance analysis was performed using footprint pattern analysis as previously described in the presence or absence of a $1 \mathrm{~cm}$ rod balance beam elevated by $3 \mathrm{~cm}$ (Dunnett et al., 1998). Open-field testing was performed as previously described (Torres et al., 2007). Open-field analysis was conducted on scaled drawings of animal movement produced by frame-to-frame examination of captured digital footage. Crossovers were determined by counting the combined number of times mice crossed their own paths during observation per min during a 10 min observation period.

Neurochemistry. Male DR $3^{\text {het }}$ and DR $3^{\text {ko }}$ mice 3 and 18 months of age were killed, and their brains were removed and microdissected on ice. Brain tissues were weighed, snap frozen using $\mathrm{LN}_{2}$, and sent for commercial analysis (RenaSci Consultancy) by HPLC to determine the level of 5-hydroxyindoleacetic acid (5-HIAA), serotonin (5-HT), 3,4dihydroxyphenylacetic acid (DOPAC), dopamine, homovanillic acid (HVA), and noradrenaline (NA).

Retrograde tracing. Intracerebral injection of the retrograde tracer Fluorogold (FG) (Fluorochrome) was performed in 3- and 18-month-old mice as previously described (Pineda et al., 2005). In brief, animals were anesthetized and placed in a stereotaxic apparatus (Stoelting), and Fluorogold solution (1\% in PBS) was injected into the striatum at the following coordinates: $\mathrm{A} / \mathrm{P}+0.5 \mathrm{~mm}, \mathrm{~L}-2 \mathrm{~mm}$ from bregma; and $\mathrm{D} / \mathrm{V} 2.7$ $\mathrm{mm}$ from dura; incisor bar set at $-3 \mathrm{~mm}$. After $2 \mathrm{~d}$, mice were perfused transcardially with $4 \%$ paraformaldehyde in PBS, cryoprotected with $30 \%$ sucrose, and frozen in dry-ice-cooled isopentane. Coronal sections $(30 \mu \mathrm{m})$ were cut on a cryostat and mounted with Mowiol (Calbiochem).

Statistical analysis. Statistical analyses were made with either Student's $t$ tests or $t$ tests assuming unequal variance if normal distributions could not be assumed. A $\chi^{2}$ test was used to compare frequency of run completion data. Unless stated otherwise, plotted data represent mean \pm SEM; $p$ values of $<0.05$ were considered significant.

\section{Results}

\section{DR3 expression in the brain is neuron specific}

Analysis of DR3 mRNA transcript levels in mouse (Wang et al., 2001b; O'Keeffe et al., 2008) and rat (Harrison et al., 2000) tissue has previously shown that DR3 is expressed using alternate length transcripts in the brain compared to lymphoid tissue. In the absence of a range of antibodies that are confirmed to recognize all variants of murine DR3 protein in histological sections, we used the $\beta$-Gal gene expressed under the control of the murine DR3 promoter (Wang et al., 2001a), to investigate the regional and developmental pattern of putative DR3 protein expression in the brains of mice. DR3 gene expression was first detected neonatally after d5 after birth and was rapidly upregulated by d9 after parturition (Fig. 1). This expression pattern was retained through early to late adulthood (Fig. $2 A-C$ ). To explore the expression pattern of DR 3 in adult DR $3{ }^{\text {het }}$ and DR $3{ }^{\text {ko }}$ mice, matched $\beta$-Galand $H \& E$-stained coronal brain serial sections ( $10 \mu \mathrm{m}$ thickness) were compared, allowing construction of DR3 promoter expression maps. Positionally, $\beta$-Gal expression was detected between the piriform cortex throughout the brain of transgenic mice to the caudal mesencephalon, disappearing at the transition to the cerebellum. In mice, the density and pattern of $\beta$-Gal staining was region specific: substantial numbers of $\beta-\mathrm{Gal}^{+}$cells were present within the hippocampal and cortical regions, but expression was undetectable in the striatum, substantia nigra, and cerebellum (Fig. 2A-C). In the hippocampus, nearly all granular (dentate gyrus) and pyramidal cells (CA1-CA3 fields) stained densely for $\beta$-Gal, whereas coloration between these layers was less frequent. In the cortex, $\beta-\mathrm{Gal}^{+}$cells were diffuse but present in all layers (Fig. $2 A, B$ ). The $\beta-\mathrm{Gal}^{+}$staining pattern found in the 

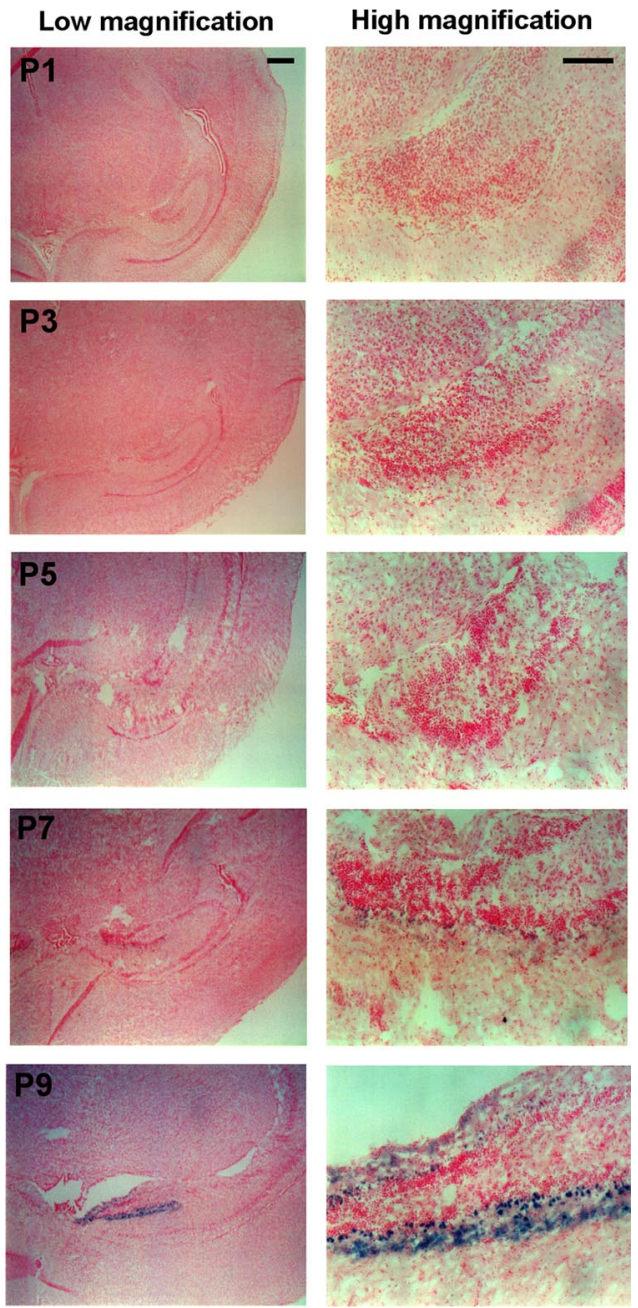

Figure 1. Developmental DR3 expression in the early postnatal murine brain. Shown is DR3 promoter-driven $\beta$-Gal expression (X-Gal, blue) in the brains of early postnatal DR3 ${ }^{\text {ko }}$ mice. Low magnification is shown in left-hand panels; high magnification in the right-hand panels at postnatal days 1 to 9 (P1 to P9) as indicated. Scale bars: $500 \mu \mathrm{m}$ for left-hand panels; $100 \mu \mathrm{m}$ for right-hand panels. The dentate gyrus is shown in each case with images representative of 2 animals per age.

brains of DR3 ${ }^{\text {ko }}$ mice was largely mirrored in age-matched DR3 ${ }^{\text {het }}$ mice, although weaker in intensity. Intriguingly, however, a severalfold greater number of $\beta-\mathrm{Gal}^{+}$cells were found throughout the cortex of DR3 ${ }^{\text {ko }}$ than in that of DR3 ${ }^{\text {het }}$ mice, suggesting an attempt to express the DR3 gene in its absence (Fig. 2A)

To confirm the basal regional pattern of DR3 expression in the brain revealed by $\beta$-Gal, an adult DR $3^{\text {wt }}$ brain was microdissected into regions and DR3 mRNA expression assessed by RTPCR. DR3 transcripts were expressed at high levels in the cortex, hippocampus, and dentate gyrus but remained undetectable in the cerebellum of adult DR3 ${ }^{\text {wt }}$ mice, consistent with DR3 localization visualized by $\beta$-Gal expression studies (Fig. $2 D$; supplemental Fig. 1, available at www.jneurosci.org as supplemental material). Some message was obtained from the DR $3{ }^{\mathrm{wt}}$ basal ganglia, but $\beta$-Gal staining was not observed in this region in DR3 ${ }^{\text {het }}$ and DR $3^{\text {ko }}$ mice. As expected, no expression of DR3 mRNA transcript was detected in DR3 ${ }^{\mathrm{ko}}$ mice (supplemental Fig. 1, available at www.jneurosci.org as supplemental material). We next used immunohistochemical studies to define the lineage of cells within the brain. In DR3 ${ }^{\text {het }}$ mice, analysis revealed that $\beta$-Gal expression colocalized almost exclusively with the neuron-specific marker, NeuN, and not with the astrocyte and glial cell marker, GFAP (Fig. 2E). These results indicate that DR3 expression is neuronlineage specific, developmentally regulated, and regionally defined in the adult mouse brain.

We next sought to determine the level and pattern of TL1A mRNA expression, the only substantiated ligand for DR3 (Kaptein et al., 2000; Migone et al., 2002; Bossen et al., 2006), in the brains of adult mice. Interestingly, expression of transcripts for TL1A mirrored that of DR3 with the highest expression found in the cortex, and the lowest expression detected in the cerebellum (Fig. 2D). More moderate TL1A mRNA expression was found in the hippocampus, colliculi, basal ganglia, and dentate gyrus (Fig. 2D). The survival, structure, and function of neurons in the brain is known to be critically dependent on glial cells (Nave and Trapp, 2008; Fiacco et al., 2009). Several studies have identified astrocytes as being responsible for intensive production of several TNF family ligands following a range of stimuli in vitro and in vivo (Sawada et al., 1989; Badie et al., 2001; Shin et al., 2002; Yan et al., 2007). We therefore purified astrocytes from the cortex of DR3 ${ }^{\mathrm{wt}}$ mice and examined whether TL1A mRNA was expressed by these cells ex vivo. Cultured astrocytes expressed low levels of transcript for murine TL1A, which was upregulated rapidly by TNF $\alpha$, suggesting that these cells may be responsible for constitutive low level provision of TL1A to local neurons within the cortex (supplemental Fig. 2, available at www.jneurosci.org as supplemental material). We also examined whether the expression levels of a range of other TNFRSF members (TNFR1, FAS, DR4/6, DR5, and $\mathrm{p} 75^{\mathrm{NTF}}$ ) or the DR3 modulator, silencer of death domain (SODD), might be altered in the absence of DR3 expression. Expression of mRNA for these proteins was comparable between DR $3^{\text {het }}$ and DR $3^{\text {ko }}$ mice by RT-PCR, indicating that loss of neuronal DR3 expression is not compensated for by upregulation of other death domain TNFRSF members (supplemental Fig. 3, available at www.jneurosci.org as supplemental material). Collectively, these studies suggest that TL1A is expressed by glial cell populations in the absence of inflammation, while expression levels of other TNF family members in the cortex of DR $3^{\mathrm{ko}}$ mice remain unaltered. The presence of constitutive cortical TL1A expression in the absence of inflammation suggests that TL1A/DR3 signaling may play an important role in normal neuronal function or maintenance in the cortex.

\section{Progressive loss of motor control in aging DR ${ }^{\mathrm{ko}}$ mice}

To assess the role of constitutive DR3 expression in normal brain function, the behavior of DR3 ${ }^{\mathrm{wt}}, \mathrm{DR} 3^{\text {het }}$, and DR3 ${ }^{\mathrm{ko}}$ mice was monitored and assessed during aging. Initial observations revealed that DR3 ${ }^{\mathrm{ko}}$ mice developed a progressive behavioral disorder characterized by abnormal gait, rapid head movement, apparent disorientation, dyskinesia, and body tremor that was triggered by environmental change such as handling, none of which were seen in DR3 ${ }^{\text {wt }}$ or DR $3^{\text {het }}$ mice. Occasionally, early aged founder mice were also found to suffer from seizures. Behavioral abnormalities were detectable in a proportion of DR3 ${ }^{\text {ko }}$ mice as young as 4 months, and the sex-independent disorder was $100 \%$ penetrant by 18 months of age (Fig. 3 ). To quantify this defect, mice were timed traversing a Perspex corridor, and measurements of stride length, width, and distance between hindpaw and forepaw placement (overlap) were made for mice aged 3 (young) and 24 (old) months. While run times between young DR $3^{\text {het }}$ and DR $3^{\text {ko }}$ and old DR $3^{\text {het }}$ mice did not differ, old DR $3^{\text {ko }}$ mice took significantly longer to complete their runs (DR3 ${ }^{\text {ko }}$ $\left.6.8 \pm 1.3 \mathrm{svs} \mathrm{DR}^{\mathrm{wt}} 3.4 \pm 0.7 \mathrm{~s} ; F_{(1,10)}=5.84, p<0.04\right)($ Fig. $4 A)$. 

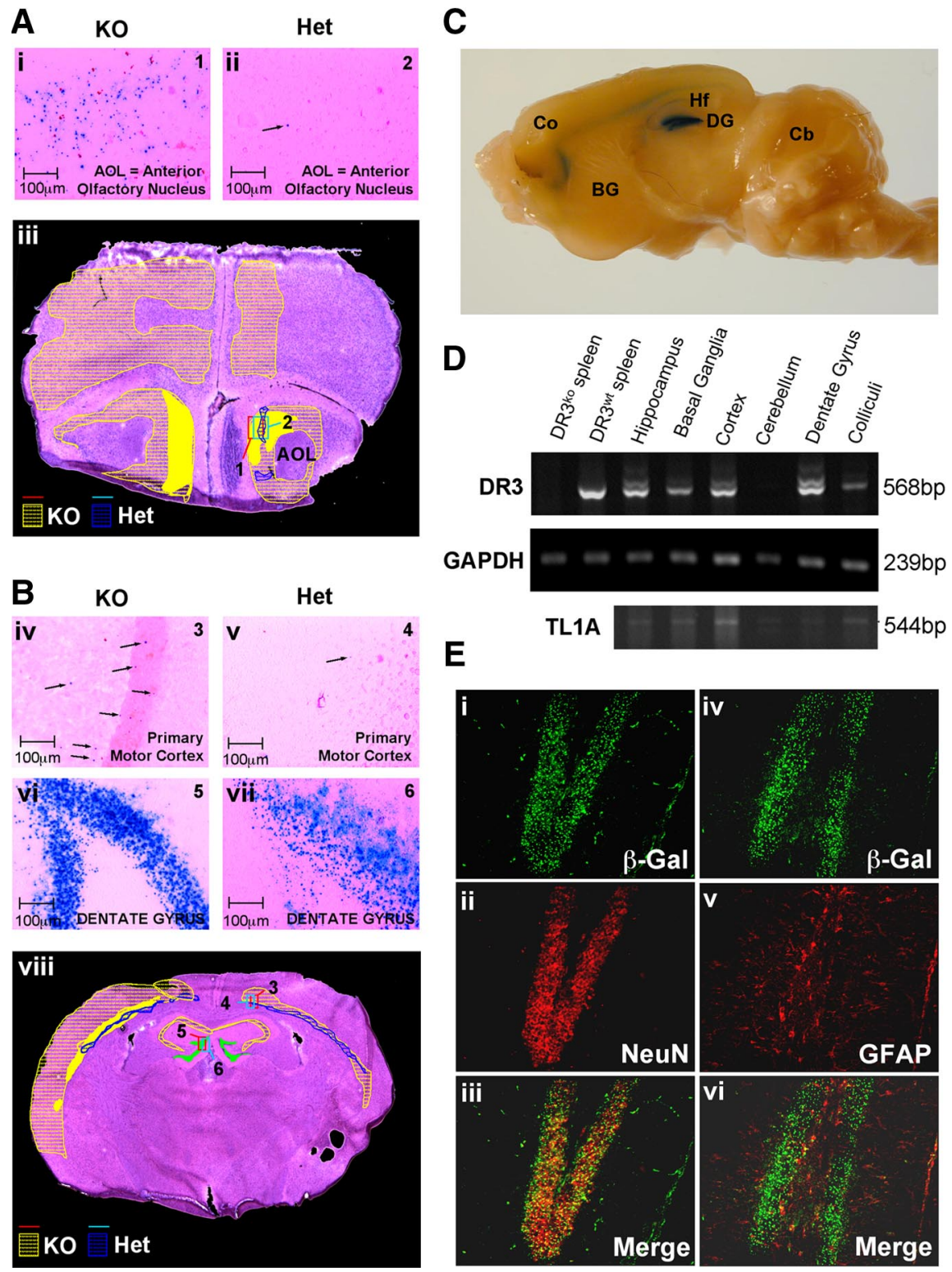

Figure 2. DR3 and TL1A expression in the adult brain. $\boldsymbol{A}, \boldsymbol{B}$, Representative images of $\beta$-Gal staining in adult DR ${ }^{\mathrm{ko}}$ and $D R 3{ }^{\text {het }}$ mice in different areas of the brain. Number of $\beta$-Gal-stained cells increased in the cortex of DR $3{ }^{\mathrm{ko}}$ mice, particularly in prefrontal areas such as the anterior olfactory nuclei $(\boldsymbol{A i}, \boldsymbol{A i i})$ and generally across other areas such as the primary motor cortex (Biv, Bv), but remained high and unchanged in the dentate gyrus (Bvi, Bvii). Comparative expression is shown for the prefrontal (Aiii) and motor cortex (Bviii). Areas in which $\beta$-Gal expression was detected are shown for DR $3^{\text {ko }}$ in yellow and DR3 ${ }^{\text {het }}$ in blue. Filled areas show high-density $\beta$-Gal staining. Areas from which high-magnification sections are shown (Ai, Aii, Biv-Bvii) are indicated by numbers with red squares for DR $3{ }^{\mathrm{ko}}$ and green squares for DR $3{ }^{\text {het }}$ animals. C, DR3 expression in DR3 ${ }^{\text {het }}$ brain as detected using the $\beta$-Gal reporter. BG, Basal Ganglia; $\mathrm{C}$, cortex; $\mathrm{Cb}$, cerebellum; DG, dentate gyrus; Hf, hippocampal formation. D, Expression of DR3 and TL1A mRNA in the indicated areas of the brain as measured by RT-PCR. GAPDH is shown as a loading control. $E$, Microscopy showing neuron-specific DR3 promoter-driven $\beta$-Gal expression in the dentate gyrus using immunofluoromicroscopy. Signals from $\beta$-Gal overlap with NeuN (Ei-Eiii), but not GFAP (Eiv-Evi).

An age-dependent difference was also detected in the gait measurements of DR3 ${ }^{\text {ko }}$ mice, a representation of which is shown in Figure $4 B$. Only old DR3 ${ }^{\text {ko }}$ mice exhibited significantly shortened forepaw stride lengths (DR3 ${ }^{\mathrm{ko}} 5.1 \pm 1.1 \mathrm{~cm}$ vs DR3 ${ }^{\mathrm{wt}} 6.3 \pm$ $\left.0.5 \mathrm{~cm} ; F_{(1,10)}=6.17, p<0.04\right)$, broader hindpaw stride width $\left(\right.$ DR $\left.^{\mathrm{ko}} 3.0 \pm 0.3 \mathrm{~cm} \mathrm{vs} \mathrm{DR3}^{\mathrm{wt}} 2.6 \pm 0.2 \mathrm{~cm} ; F_{(1,10)}=9.84, p<0.02\right)$, and decreased overlap relative to matched controls (DR3 ${ }^{\text {ko }}$ $1.4 \pm 0.6 \mathrm{~cm}$ vs DR3 ${ }^{\mathrm{wt}} 0.7 \pm 0.2 \mathrm{~cm} ; F_{(1,10)}=8.11, p<0.02$ ) (Fig. $4 C)$. We also explored whether the balance of DR ${ }^{\text {ko }}$ mice might also be impaired by defective motor control as found for some models of neurological disease (Fernagut et al., 2004; Truong et al., 2006). Aged DR3 ${ }^{\text {het }}$ mice all traversed the $60 \mathrm{~cm}$ long balance beam on all three runs in an average time of $11.4 \pm$ 0.6 s. In contrast, the DR $3^{\text {ko }}$ mice had much greater difficulty completing the task: only two of the eight mice succeeded in crossing the beam within the $120 \mathrm{~s}$ observation period on all three runs, three failed on one or two occasions to cross, and three failed on all three occasions (Fig. 5A). For purposes of analysis, failed runs were allocated a maximum crossing time of $120 \mathrm{~s}$, yielding a group mean latency to cross of $83.0 \pm 15.7 \mathrm{~s}$, which was significantly longer than that taken by the DR3 ${ }^{\text {het }}$ group $\left(F_{(1,13)}=18.09, p<0.003\right)$ (Fig. $5 B$ ). While loss of footing by well balanced adult DR3 $3^{\text {het }}$ mice was rare, movement by DR $3^{\text {ko }}$ mice was marked by frequent imbalance, foot slippage, and stationary behavior (Fig. 5C).

We next examined the movement and exploratory behavior of DR3 ${ }^{\mathrm{ko}}$ mice by comparing the activity of transgenic mice during open-field tests using a graduated $1 \mathrm{~m}$ Perspex square. Compared to 24month-old DR3 ${ }^{\text {het }}$ controls, similarly aged DR3 ${ }^{\text {ko }}$ mice exhibited hyperactivity and increased complexity of movement characterized by rapid, abrupt changes in forward direction and path crossing with some animals showing strong circling behavior (supplemental Videos 1-3, available at www.jneurosci.org as supplemental material) (Fig. 6A). In a 10 min observation period, DR ${ }^{\mathrm{ko}}$ mice traversed an average of $250 \%$ more accumulative open space, covering $89 \pm 17 \mathrm{~m}$ relative to DR $3^{\text {het }}$ controls, which traversed $35 \pm 5 \mathrm{~m}\left(F_{(1,10)}=\right.$ $8.87, p<0.02$ ) (Fig. 6B). The relative complexity of DR3 ${ }^{\text {ko }}$ mice open-field activity also increased compared to DR3 ${ }^{\text {het }}$ mice as determined by the frequency mice crossed their own path, with DR3 ${ }^{\text {ko }}$ mice averaging this readout $286 \pm 86$ times over $10 \mathrm{~min}$, $\sim 14$ times more frequently than their DR3 ${ }^{\text {het }}$ counterparts who averaged this $20 \pm 6$ times $\left(F_{(1,10)}=9.47, p<0.02\right)$ (Fig. $6 B)$. This increased locomotor complexity was not due to their hyperactivity as the average distance traveled before a crossover event was significantly shorter in DR $3^{\text {ko }}$ mice than in DR $3^{\text {het }}$ controls $\left(\mathrm{DR} 3^{\mathrm{ko}} 0.41 \pm 0.07 \mathrm{~m}\right.$ vs DR3 ${ }^{\mathrm{wt}} 2.5 \pm 0.5 \mathrm{~m}$; $F_{(1,10)}=16.83, p<0.003$ ) (Fig. $6 C$ ). No directional preference was observed in the circling behavior of individual mice during open-field tests regardless of age or sex. Similar results were obtained with DR $3^{\mathrm{ko}}$ mice that had been crossed with CD1 (outbred) mice for two generations (data not shown), demonstrating that the dysfunction was not due to a specific genetic background. Collectively, these results confirm that DR3 ${ }^{\text {ko }}$ mice 


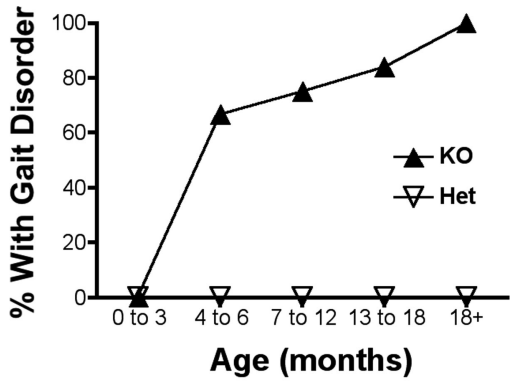

No. of Mice

$\begin{array}{lcccc}\text { Ko } & 3 & 12 & 13 & 9 \\ \text { Het } & 10 & 10 & 14 & 21\end{array}$

Figure 3. Time course of development of observable gait disorders in DR $3^{\mathrm{k} 0}$ mice. Proportion of DR3 ${ }^{\mathrm{ko}}$ and DR3 ${ }^{\text {het }}$ mice showing observable gait disorder with age. Numbers under the graph represent numbers of mice per age group assessed.

develop significant motor coordination problems, hyperactivity, and abnormal exploratory behavior in an age-dependent manner.

Dysregulated dopamine and serotonin expression in the striatum of aged DR $3^{\mathrm{ko}}$ mice

We next determined whether the behavioral abnormalities exhibited by aged DR ${ }^{\mathrm{ko}}$ mice were associated with altered levels of neurotransmitters in the brain. Brains from 3-and 18-month-old mice were microdissected into the cortex, striatum, hippocampus, and cerebellum, and the levels of neurotransmitters assessed by HPLC. Brains from DR ${ }^{\text {ko }}$ mice appeared histologically normal being devoid of apparent cellular infiltrates, lesions/plaques, upregulated inflammatory markers, and apparent inflammation as assessed by immunohistochemistry (unpublished observations). Weights of whole and individually dissected regions of brain were also similar between DR $3^{\text {ko }}$ and DR $3^{\text {het }}$ animals (supplemental Fig. 4, available at www.jneurosci.org as supplemental material). Young DR $3^{\mathrm{ko}}$ and DR $3^{\mathrm{wt}}$ mice (3 months of age) showed no significant differences in neurotransmitter levels in the brain, but strikingly, we found that dopamine levels within the striatum of 18-month-old DR3 ${ }^{\text {ko }}$ mice were $60 \%$ higher than their DR3 ${ }^{\text {het }}$ counterparts (DR3 ${ }^{\text {ko }} 15,546 \pm 1163 \mathrm{ng} / \mathrm{g}$ tissue vs DR3 ${ }^{\text {het }} 9768 \pm$ $2383 \mathrm{ng} / \mathrm{g}$ tissue; $\left.F_{(1,9)}=5.32, p<0.05\right)$, while serotonin was fourfold lower (DR3 ${ }^{\text {ko }} 77 \pm 21 \mathrm{ng} / \mathrm{g}$ tissue vs DR3 ${ }^{\text {het }} 328 \pm 81$ ng/g tissue; $F_{(1,9)}=10.63, p<0.01$ ) (Table 1$)$. These changes could not be explained by a failure of dopamine breakdown, as the ratios of dopamine to dopamine metabolites (DOPAC, HVA) were unchanged (Table 1; supplemental Fig. 5, available at www. jneurosci.org as supplemental material). Furthermore, it could not be explained by upregulation of $\mathrm{TH}$, the primary enzyme responsible for dopamine production, as TH levels throughout the brain were comparable between DR3 ${ }^{\text {ko }}$ and DR3 ${ }^{\text {wt }}$ controls as assessed by immunohistochemistry on coronally matched sections (Fig. $7 A, B$ ). These data demonstrate that despite an absence of overt neurological pathology, aged DR $3^{\mathrm{ko}}$ mice have profound differences in striatal neurochemistry.

\section{Corticostriatal innervation is DR3 dependent in aging} DR3 ${ }^{\text {ko }}$ mice

Current literature suggests that DR3 can control cell fate by initiating either proliferative or apoptotic signaling (Chinnaiyan et al., 1996; Kitson et al., 1996; Marsters et al., 1996; Migone et al., 2002). We therefore examined whether neuronal lifespan might be altered in the absence of DR3 expression in vivo by examining
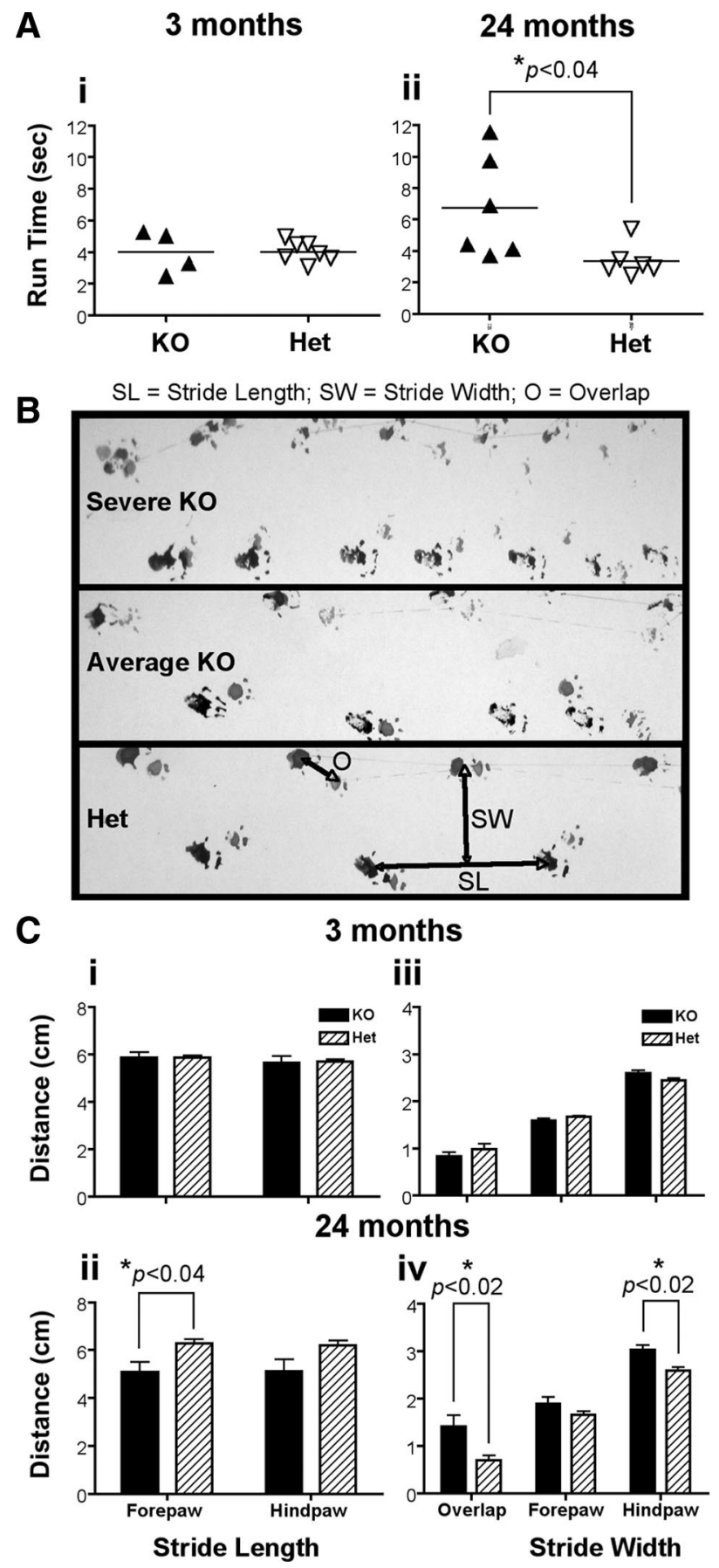

Figure 4. Defects in gait in aged DR $3{ }^{\mathrm{ko}}$ mice. Gait defects in 3-month- or 2-year-old mice were compared using timed footprint and movement analysis. $A$, Average run time for young and old mice. $\boldsymbol{B}$, Representative footprints of DR3 ${ }^{\mathrm{ko}}$ and DR3 ${ }^{\text {het }}$ mice are shown. $\boldsymbol{C}$, Footprint analysis showing stride length $(\boldsymbol{i}, \mathbf{i})$ and stride width and overlap $($ iii, $i \boldsymbol{i v})$ of young $(\boldsymbol{i}$, iii) and old (ii, iv) mice. * Student's $t$ tests showed significant differences as indicated.

neuron numbers in aged mice. The number of $\mathrm{NeuN}^{+}$cells present in aligned sections from the brains of aged DR $3^{\text {het }}$ and DR $3^{\text {ko }}$ mice showed no significant difference following twodimensional histological topographic analysis (Fig. $8 \mathrm{~A}$ ). The area and thickness of individual layers or regions of the brain as calculated by computer topography was also found to be similar between DR3 ${ }^{\text {het }}$ mice and their controls (supplemental Table 2, available at www.jneurosci.org as supplemental material). No difference was also found in the number of apoptotic neurons in 

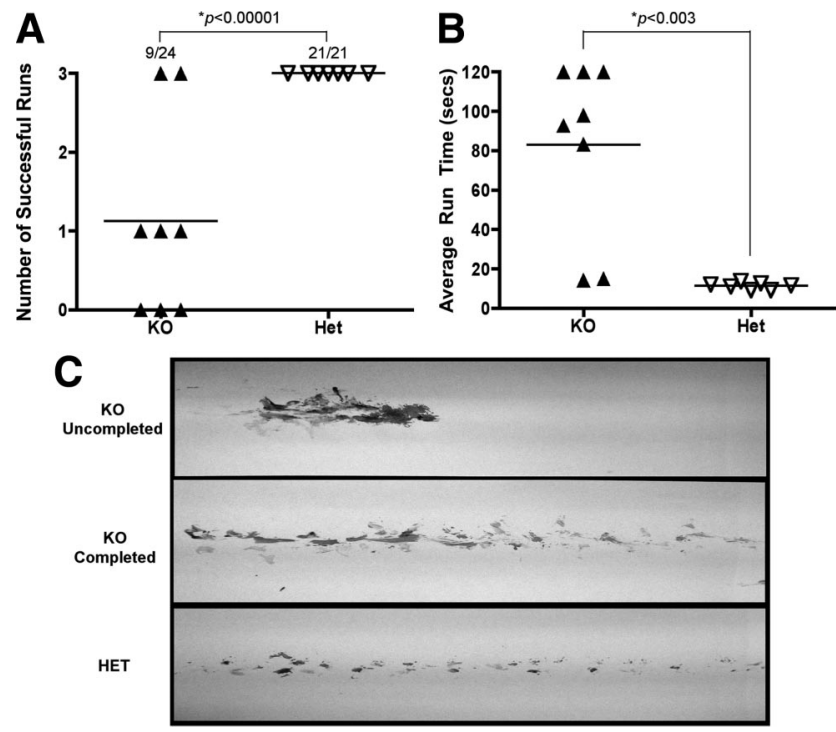

Figure 5. Defects in balance in aged DR3 ${ }^{\mathrm{ko}}$ mice. Balance was compared in 2-year-old $D R 3^{\text {het }}$ and DR3 ${ }^{{ }^{k 0}}$ mice by timing of runs along a raised balance beam within a $60 \mathrm{~cm}$ run. $A$, Completion frequency for DR $3{ }^{\text {het }}$ and DR ${ }^{\mathrm{k} o}$ mice. $\chi^{2}$ test showed significant difference as indicated. $\boldsymbol{B}$, Average run times for DR3 $3{ }^{\text {het }}$ and DR3 ${ }^{\mathrm{ko}}$ mice, with animals not completing given a maximum time of $120 \mathrm{~s}$. Each point represents the average from 3 runs from an individual animal. *Student's $t$ test assuming unequal variance showed significant differences as indicated. $C$, Representative footprints of DR3 ${ }^{\text {ko }}$ and DR3 ${ }^{\text {het }}$ mice are shown.

the brains of adult DR3 ${ }^{\text {ko }}$ mice, compared to controls, which were barely detectable (unpublished observations) in agreement with others (Yang et al., 2008). Together, these data suggest that DR3 plays no overt role in the normal determination of neuron lifespan in adult mice in vivo.

Given that aged DR ${ }^{\mathrm{ko}}$ mice had normal neuron numbers and DR3 was not expressed in the striatum, we next hypothesized that corticostriatal innervation might be altered by the loss of neuronal DR3 expression, as has been recently observed for another TNFRSF member, GITR (O'Keeffe et al., 2008). This was directly assessed by injection of the retrograde axonal tracer FG into the striatum of mice. The cortex of 18 -month-old DR $3^{\text {ko }}$ mice had significantly lower numbers of FG-labeled pyramidal cells than similarly treated control animals (Fig. $8 B, C$ ). Overall, $>25 \%$ of corticostriatal contact had been lost in aging DR3-deficient mice in the absence of continued cortical DR3 expression by neurons as indicated by retrograde tracing (DR3 ${ }^{\text {ko }} 74.7 \pm 2.7 \%$ vs DR3 ${ }^{\text {wt }}$ $100 \pm 8.5 \%$ of normal cortical density; $\left.F_{(1,6)}=8.25, p<0.03\right)$. No significant differences were observed between young ( 3 months old) DR3 ${ }^{\mathrm{wt}}(100 \pm 8 \%)$ and DR3 ${ }^{\mathrm{ko}}(95 \pm 2 \%)$ mice (Fig. $8 C)$. These results demonstrate that continued neuronal DR3 expression is important for the normal, long-term maintenance of neuronal innervation between the cortex and striatum in adult mice in the absence of appreciable neuron loss. It is less likely that there is a developmental deficit, since there were no differences in innervation density between 3-month-old animals.

\section{Discussion}

In this study, we demonstrate for the first time that DR3 is critically required for maintaining neural connectivity between the cortex and striatum during aging, which is necessary for normal motor control function. DR $3^{\text {ko }}$ mice develop a progressive locomotor disorder defined by deficits in coordinated movement and gait, which emerges during early adulthood, appears sex independent, and is $100 \%$ penetrant. The behavioral phenotype of DR3 ${ }^{\text {ko }}$
A

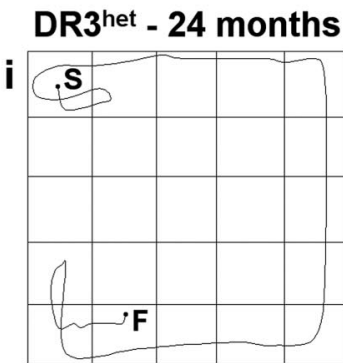

B

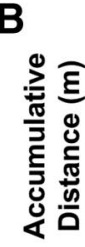

3 months

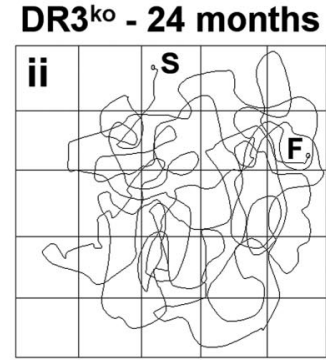

24 months
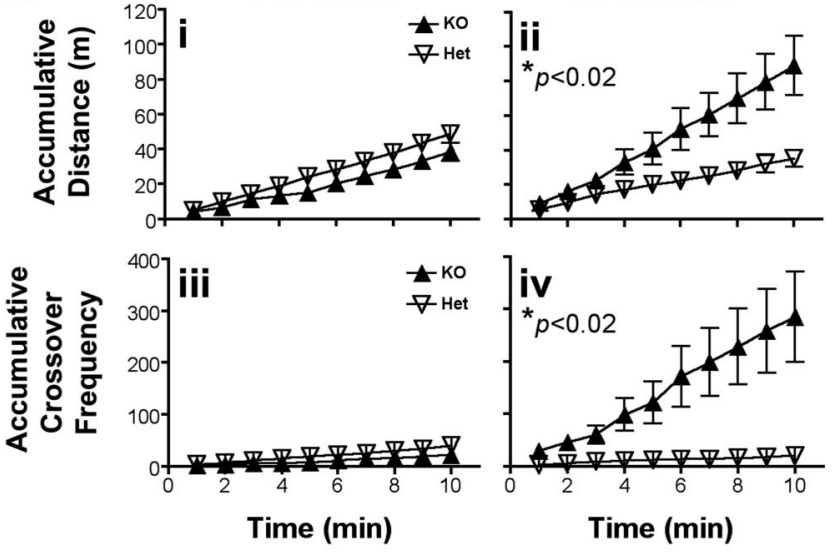

C

$$
\text { i }
$$

ii
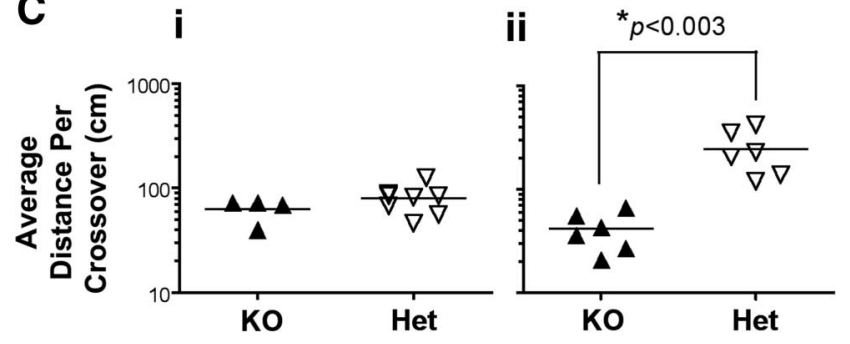

Figure 6. Hyperkinesia and increased movement complexity in DR $3{ }^{\mathrm{ko}}$ mice. $\boldsymbol{A}$, Representative plots of the movement of digitally tracked mice in a $1 \mathrm{~m}$ square open field over $1 \mathrm{~min}(n=$ 6-8 per group). S, Start; F, finish. $\boldsymbol{B}$, Accumulative distance traversed (i, ii) and accumulative frequency of path-crossing events (iii, iv) displayed by young $(\boldsymbol{i}, \mathbf{i i i})$ and old (ii, iv) DR3 ${ }^{\text {ko }}$ and DR3 ${ }^{\text {het }}$ mice during $10 \mathrm{~min}$. C, Average distance traversed before mice crossed their own paths. Each group included 4-8 mice, and data are representative of four experiments. Asterisks in relevant panels indicate significance of Student's $t$ tests. Lines and error bars represent mean \pm SEM.

mice resembles a milder form of that observed in jerker mice, which carry a recessive point mutation that disrupts the expression of the actin-bundling protein espin in hair cell stereocilia (Zheng et al., 2000). Because espin lies next to DR3 in the murine genome, we studied espin protein expression by Western blotting and found no difference between DR $3^{\text {wt }}$ and DR $3^{\text {ko }}$ kidney, a tissue in which small espin is found in brush border microvilli (Bartles et al., 1998) (supplemental Fig. 6, available at www. jneurosci.org as supplemental material). This suggests that espin expression is unaffected in DR $3^{\mathrm{ko}}$ mice and that the phenotype of the mice is DR3 specific. Importantly, advancing loss of motor control in DR3 ${ }^{\text {ko }}$ mice occurred through a relatively passive process without the induction of apparent inflammation, alteration to other TNFRSF brain expression levels or radical changes in neuron number. Thus, we propose that low endogenous TL1A stimulation of $\mathrm{DR}^{+}$cortical neurons stimulates the maintenance of interneuronal contact with adjoining dopaminergic or serotonergic striatal neurons. Supporting this, we observed in 
Table 1. Concentration of neurochemicals in the DR3 ${ }^{\mathrm{ko}}$ and DR3 ${ }^{\text {het }}$ brain

\begin{tabular}{|c|c|c|c|c|c|c|}
\hline \multirow[b]{2}{*}{ Area of brain } & \multicolumn{6}{|c|}{ Neurochemical concentration (ng/g wet weight) $^{a}$} \\
\hline & 5-HIAA & 5-HT & DOPAC & DOPAMINE & HVA & NA \\
\hline \multicolumn{7}{|l|}{ Hippocampus } \\
\hline Young DR3 $3^{\text {het }}$ & $448 \pm 36$ & $661 \pm 26$ & $12 \pm 1^{*}$ & $24 \pm 5$ & $40 \pm 3$ & $584 \pm 31^{*}$ \\
\hline Young DR3 ${ }^{\text {ko }}$ & $392 \pm 40$ & $635 \pm 40$ & $16 \pm 1^{*}$ & $24 \pm 2$ & $43 \pm 1$ & $496 \pm 20^{*}$ \\
\hline Old DR3 ${ }^{\text {het }}$ & $479 \pm 48$ & $602 \pm 100$ & $8 \pm 4$ & $43 \pm 16^{b}$ & $28 \pm 5$ & $491 \pm 54$ \\
\hline Old DR3 ${ }^{\text {ko }}$ & $542 \pm 18$ & $695 \pm 38$ & $0.4^{c}$ & $51^{c}$ & $31 \pm 5$ & $572 \pm 29$ \\
\hline \multicolumn{7}{|l|}{ Mesencephalon } \\
\hline Young DR3 ${ }^{\text {het }}$ & $646 \pm 25$ & $1261 \pm 30$ & $126 \pm 9$ & $368 \pm 35$ & $249 \pm 26$ & $746 \pm 25$ \\
\hline Young DR3 ${ }^{\text {ko }}$ & $587 \pm 17$ & $1173 \pm 26$ & $138 \pm 16$ & $359 \pm 56$ & $234 \pm 33$ & $738 \pm 49$ \\
\hline Old DR3 $3^{\text {het }}$ & $696 \pm 53$ & $945 \pm 46$ & $52 \pm 14$ & $189 \pm 32$ & $122 \pm 21$ & $638 \pm 44$ \\
\hline Old DR3 ${ }^{\text {ko }}$ & $663 \pm 61$ & $907 \pm 32$ & $69 \pm 7$ & $190 \pm 19$ & $130 \pm 10$ & $754 \pm 55$ \\
\hline \multicolumn{7}{|l|}{ Striatum } \\
\hline Young DR3 ${ }^{\text {het }}$ & $329 \pm 44$ & $488 \pm 35$ & $627 \pm 73$ & $5589 \pm 190$ & $1282 \pm 175$ & $153 \pm 24$ \\
\hline Young DR3 ${ }^{\text {ko }}$ & $288 \pm 19$ & $479 \pm 31$ & $782 \pm 73$ & $5952 \pm 188$ & $1359 \pm 160$ & $156 \pm 49$ \\
\hline Old DR3 $3^{\text {het }}$ & $290 \pm 45$ & $328 \pm 81^{*}$ & $743 \pm 158^{*}$ & $9768 \pm 2383^{*}$ & $717 \pm 106^{*}$ & $221 \pm 35$ \\
\hline Old DR3 ${ }^{\text {ko }}$ & $340 \pm 31$ & $77 \pm 21^{*}$ & $1251 \pm 84^{*}$ & $15546 \pm 1163^{*}$ & $1047 \pm 66^{*}$ & $197 \pm 27$ \\
\hline \multicolumn{7}{|l|}{ Rest of brain } \\
\hline Young DR3 ${ }^{\text {het }}$ & $267 \pm 19$ & $445 \pm 16$ & $81 \pm 6$ & $485 \pm 39$ & $191 \pm 13$ & $515 \pm 24$ \\
\hline Young DR3 ${ }^{\text {ko }}$ & $240 \pm 18$ & $438 \pm 8$ & $92 \pm 3$ & $489 \pm 42$ & $186 \pm 9$ & $509 \pm 10$ \\
\hline Old DR3 ${ }^{\text {het }}$ & $384 \pm 19$ & $431 \pm 22$ & $189 \pm 20^{*}$ & $542 \pm 61$ & $130 \pm 14$ & $562 \pm 43^{*}$ \\
\hline Old DR3 ${ }^{\text {ko }}$ & $349 \pm 14$ & $432 \pm 41$ & $131 \pm 9^{*}$ & $524 \pm 36$ & $147 \pm 9$ & $439 \pm 31^{*}$ \\
\hline
\end{tabular}

Young mice were 3 months of age; old mice were 18 months of age; experiments on young and old animals were carried out at different times, so only age-matched animals were compared statistically.

${ }^{a}$ Values are mean \pm SEM, calculated from 5 young DR3 ${ }^{\mathrm{ko}}, 5$ young DR3 ${ }^{\text {het }}, 6$ old DR $3{ }^{\mathrm{ko}}$, and 5 old DR $3{ }^{\text {het }}$ male mice unless otherwise stated.

${ }^{b}$ Value calculated from 3 mice (others gave values below detection of the assay).

Value calculated from 1 mouse (others gave values below detection of the assay).

*Student's $t$ test between DR3 ${ }^{\text {het }}$ and DR3 ${ }^{\mathrm{ko}}$ values showed significance at $p<0.05$.
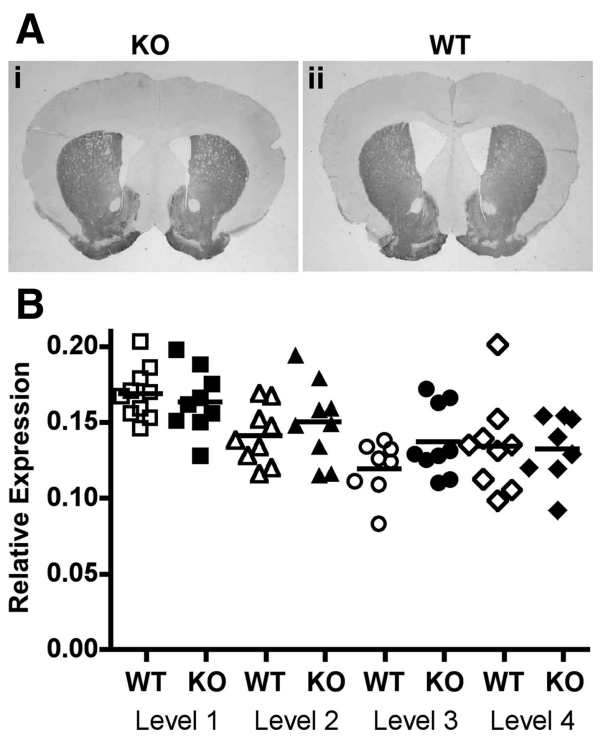

Figure 7. Expression of tyrosine hydroxylase in the brain. $\boldsymbol{A}$, Immunohistochemistry showing TH expression in DR3 ${ }^{\mathrm{k} o}(\boldsymbol{i})$ and DR3 ${ }^{\text {wt }}$ (ii) mice. $\boldsymbol{B}$, Summary data showing no difference in TH expression at all matched levels throughout the striatum between DR3 ${ }^{\mathrm{k} o}$ and DR3 ${ }^{\text {wt }}$ mice.

vitro expression of TL1A mRNA from cultured astrocytes isolated from the cortex, the primary site of TL1A transcript expression in vivo. How might TL1A promote DR3-dependent innervation? One possibility is that TL1A may contribute directly to axon growth or dendrite formation in aging neurons such as occurs following FasL treatment of embryonic neurons (Zuliani et al., 2006) and GITRL treatment of neonatal sympathetic neurons (O'Keeffe et al., 2008). Alternatively, TL1A may increase neuron excitability or alter ion channel signaling as has been shown for TNF $\alpha$ (Diem et al., 2001; Ogoshi et al., 2005; Ozaktay et al., 2006; Czeschik et al., 2008). In such cases, more frequent neuronal stimulation would be predicted to drive new synapse/dendrite formation and stabilization (De Roo et al., 2008). Importantly, our results suggests that the maintenance of adult neuronal corticostriatal projections formed earlier during development and critical for motor control is dependent on the continued reception of low level DR3 signaling by neurons involved in these contacts.

The expression of transcripts for TL1A throughout many parts of the brain in a region-specific manner is also a novel finding. Before this study, TL1A has been reported to be found in serum (Bamias et al., 2008), human umbilical vein endothelial cells (Yang et al., 2004), and myeloid and T-cells (Bamias et al., 2003; Cassatella et al., 2007; Prehn et al., 2007; Meylan et al., 2008). TL1A has been reported to have roles in mucosal immunity (Papadakis et al., 2005), inflammatory bowel disease (Bamias et al., 2006; Takedatsu et al., 2008), inflammatory arthritis (Borysenko et al., 2006; Cassatella et al., 2007; Bull et al., 2008), renal inflammation (Al-Lamki et al., 2008), asthma (Fang et al., 2008; Meylan et al., 2008), and autoimmune encephalitis (Meylan et al., 2008; Pappu et al., 2008). Since the brains of DR3deficient animals have normal cell numbers and appear devoid of any inflammation or apparent neuropathology, this suggests that cerebral mechanisms exist to dampen neuronal DR3 responsiveness, which is likely to be very threshold or age sensitive. This might be expected as TL1A seems to be constitutively produced by cells within the brain in regions where $\mathrm{DR} 3^{+}$neurons cohabit.

Progressive behavioral defects in DR ${ }^{\mathrm{ko}}$ mice paralleled the differential expression of striatal neurotransmitters with increased dopamine and a corresponding serotonin reduction. Dopamine signaling appears essential for motivated behavior as shown by severe defects in feeding, motor control, and rewardbased learning apparent in Dopamine ${ }^{\text {ko }}$ mice (Zhou and Palmiter, 1995; Palmiter, 2008). Serotonin receptor familydeficient mice also display altered locomotion and behavior (Lesch et al., 2003). Moreover, serotonin and dopamine imbalances are prominently associated with human neurological dis- 


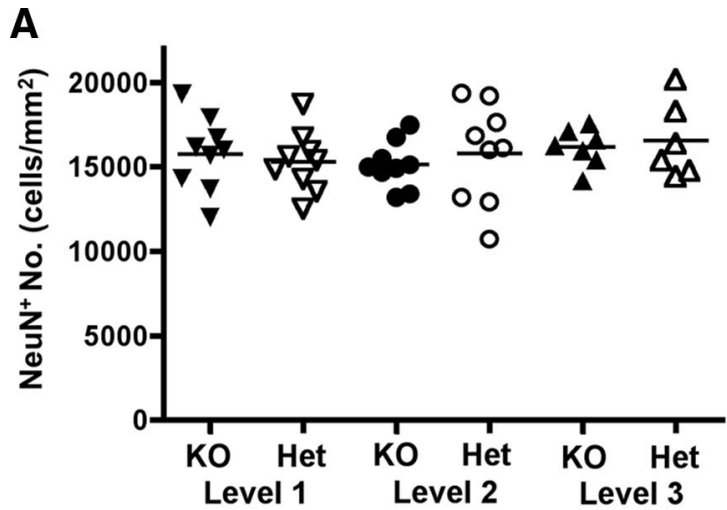

B

KO

18 months

WT
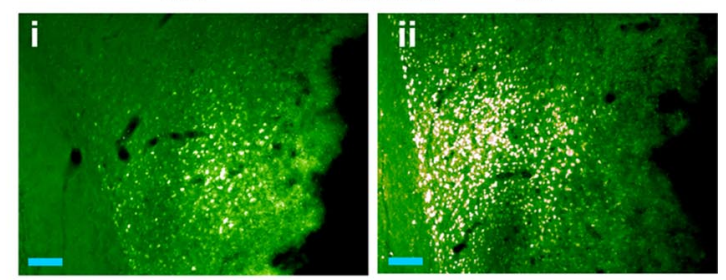

C

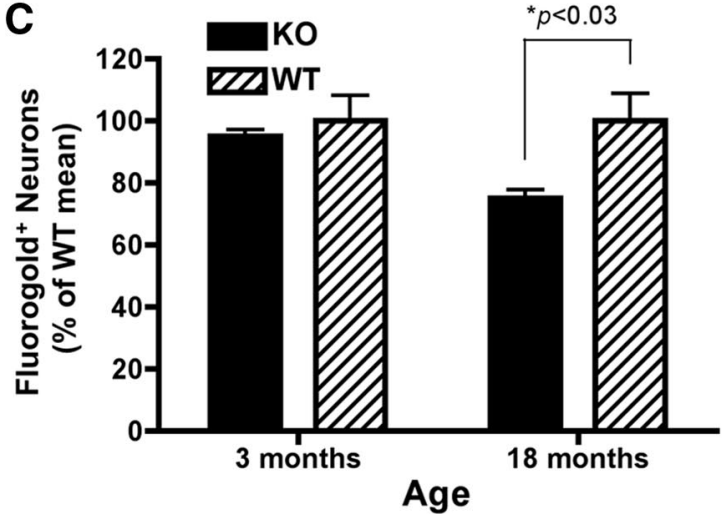

Figure 8. Alterations in corticostriatal innervation in the absence of changes of neuronal number in DR3 ${ }^{\mathrm{ko}}$ mice. $\boldsymbol{A}$, Stereological counting of $\mathrm{NeuN}^{+}$cells showed no difference between DR3 ${ }^{\text {ko }}$ and DR3 ${ }^{\text {het }}$ mice at 4 different matched levels in the brain. Data are mean \pm SEM from $n=9$ mice. $\boldsymbol{B}, \boldsymbol{C}$, Retrograde tracing of innervation into the striatum. $\boldsymbol{B}$, Representative images from the cortex of 18 -month-old DR3 ${ }^{\text {ko }}$ (i) and DR3 ${ }^{\text {wt }}$ (ii) mice. Scale bars, 100 $\mu \mathrm{m}$. C, Young (3 months of age) DR3 ${ }^{\mathrm{ko}}$ and DR3 ${ }^{\text {wt }}$ mice showed equivalent corticostriatal innervation, while old ( 18 months of age) DR3 ${ }^{\mathrm{k} o}$ mice showed a reduction in corticostriatal innervation compared to age-matched DR3 ${ }^{\text {wt }}$ mice. Data are percentage of the agematched DR3 ${ }^{\text {wt }}$ mean \pm SEM from $n=4$ mice. Statistical significance of ${ }^{*} p<0.03$ using a Student's $t$ test.

orders ranging from Parkinson's disease to schizophrenia and circling in mice (Nieoullon and Coquerel, 2003; Ishiguro et al., 2007; Di Matteo et al., 2008). The biosynthesis of dopamine occurs in a two stage process in which L-tyrosine is first converted to L-DOPA, by the enzyme TH, and then L-DOPA is converted to dopamine, by the enzyme DOPA decarboxylase (Zhou and Palmiter, 1995). Striatal dopamine levels appear dependent on production by DA neurons projected from the substantia nigra $(\mathrm{SN})$ as changes in striatal dopamine often reflect alteration to SN neuron number (Kramer et al., 2007). In aged DR ${ }^{\text {ko }}$ mice, however, we show that striatal dopamine levels were elevated to $160 \%$ in the absence of any change to brain neuron numbers or alteration in the level or pattern of TH expression. We also found that the levels of two products generated from the breakdown of dopamine, DOPAC and HVA, were found in normal ratios, suggesting that a failure of striatal dopamine metabolism was not responsible for increase levels of this neurotransmitter. It has been suggested that continued dopamine expression is important for the correct maintenance of corticostriatal synapses, as unilateral destruction of dopaminergic striatal input leads to innervation failure (Arbuthnott et al., 2000). However, whether a specific loss of corticostriatal innervation can induce a corresponding upregulation of striatal dopamine remains unclear. Alternatively, neurotransmitter dysregulation in DR ${ }^{\mathrm{ko}}$ mice may reflect the absence of direct DR3-dependent alteration of neurotransmitter production or subsequent synaptic sensitivity as triggered by TNF $\alpha$ (Schafers and Sorkin, 2008). Both models are consistent with the hypothesis that behavioral defects in dopaminedependent disorders may reflect corticostriatal pathway dysfunction, as found in DR3 ${ }^{\mathrm{ko}}$ mice, rather than just changes to cortical activity (Costa et al., 2006).

Striatal serotonin levels were also reduced by $73 \%$ in adult DR $3^{\text {ko }}$ mice. There is evidence to suggest that excessive dopamine production can inhibit serotonin production by serotonergic neurons in the striatum in vivo leading to behavioral defects. Many Parkinson's disease patients receiving long-term L-DOPA treatment suffer motor control loss associated with dopamine dysregulation (Cenci and Lindgren, 2007). Similarly, dopamine uptake, production, storage, and release can supplant and deplete serotonin in striatal serotonin neurons following chronic L-DOPA treatment in several models (Kannari et al., 2006; Yamada et al., 2007; Carta et al., 2008). We therefore suggest that excessive striatal dopamine production in DR3 ${ }^{\text {ko }}$ mice is downregulating serotonin expression and that neuronal DR3 signaling is likely to be a major inhibitory dampener suppressing dopamine induction in vivo.

The role of basal TNFRSF member brain expression and function is an emerging field with few published studies. In vitro, select TNFSRF members have been shown to promote nerve growth and function (Shao et al., 2005; Czeschik et al., 2008; Hayashi et al., 2008; Hou et al., 2008; O’Keeffe et al., 2008). Constitutive brain expression of some TNFRSF receptors has also been reported (Yan and Johnson, 1988; Pan et al., 1998; Eby et al., 2000; Kojima et al., 2000; Tan et al., 2002; Pispa et al., 2003; Shao et al., 2005; Zuliani et al., 2006; Hamill et al., 2007; Catts et al., 2008; Harry et al., 2008; Hou et al., 2008; O’Keeffe et al., 2008), but the neurological function of most members remains unknown. The extensive behavioral and neurochemical defects exhibited by DR $3^{\text {ko }}$ mice are unique among TNFRSF ${ }^{\text {ko }}$ mice. For example, TNFR $1^{\text {ko }}$ mice have normal striatal dopamine/metabolite levels (Leng et al., 2005) and locomotor activity, exhibiting standard behavioral responses in several tests (e.g., open field and Porsholt swim) (Simen et al., 2006; Quintana et al., 2007; Baracchi and Opp, 2008). Why DR3 ${ }^{\text {ko }}$ mice, among TNFRSF-deficient animals, uniquely develop severe and progressive neurological defects requires further study but probably reflects receptor differences in function and endogenous age-related expression. In this respect, we first show that continued neuronal DR3 signaling functions by uniquely promoting region-specific (corticostriatal) brain innervation. Second and regardless of the mechanism, basal neuronal DR3 appears to functionally regulate the expression of two key neurotransmitters required for movement and behavior, dopamine and serotonin. Thirdly, we note that stable postnatal neuronal DR3 expression appears more intense and widespread in the cortex and hippocampus than most TNFRSF members in brain regions with motor control pathway function. No other TNFRSF member has been similarly reported to functionally promote the stabilization of preexisting adult neural pathways and regulate striatal neurotransmitter expression under normal 
conditions in vivo. TNF $\alpha$, though, has been shown to act as a gliotransmitter, altering synaptic transmission (Stellwagen et al., 2005) and controlling synaptic strength (Beattie et al., 2002) and scaling (Stellwagen and Malenka, 2006), while other proinflammatory cytokines such as IL-1 can influence synaptic plasticity (Ross et al., 2003). The interactions between TL1A and these cytokines in the brain are poorly understood and remain an important area of further investigation. Our data are consistent with the suggestion that the key neurological function of individual TNFRSF receptors is likely to be developmentally, functionally, and regionally compartmentalized within the brain.

In this report, we identify neuronal DR3 signaling as being mandatory for normal striatal neurotransmitter expression and maintenance of corticostriatal neural pathways, which are essential for normal motor control function in the aging adult. How DR3 signaling provides pathway stabilization cues to these neural networks remains an important issue to be resolved; however, the observation that aging DR3 ${ }^{\mathrm{ko}}$ mice acquire defective neurotransmitter expression and progressive motor control loss provides a unique insight into this proinflammatory receptor. Importantly, this study demonstrates that DR3 plays a key nonredundant role in behavior and normal adult brain homeostasis, further expanding upon the essential roles that TNFSFR members play within the mammalian body. As such, we identify DR3 as a primary molecular target for future neuromodulatory and neurodegenerative disease research.

\section{References}

Albin RL, Young AB, Penney JB (1989) The functional anatomy of basal ganglia disorders. Trends Neurosci 12:366-375.

Al-Lamki RS, Wang J, Thiru S, Pritchard NR, Bradley JA, Pober JS, Bradley JR (2003) Expression of silencer of death domains and death-receptor-3 in normal human kidney and in rejecting renal transplants. Am J Pathol 163:401-411.

Al-Lamki RS, Wang J, Tolkovsky AM, Bradley JA, Griffin JL, Thiru S, Wang EC, Bolton E, Min W, Moore P, Pober JS, Bradley JR (2008) TL1A both promotes and protects from renal inflammation and injury. J Am Soc Nephrol 19:953-960.

Andrews-Hanna JR, Snyder AZ, Vincent JL, Lustig C, Head D, Raichle ME, Buckner RL (2007) Disruption of large-scale brain systems in advanced aging. Neuron 56:924-935.

Arbuthnott GW, Ingham CA, Wickens JR (2000) Dopamine and synaptic plasticity in the neostriatum. J Anat 196:587-596.

Ashkenazi A, Dixit VM (1998) Death receptors: signaling and modulation. Science 281:1305-1308.

Badie B, Schartner J, Prabakaran S, Paul J, Vorpahl J (2001) Expression of Fas ligand by microglia: possible role in glioma immune evasion. J Neuroimmunol 120:19-24.

Bamias G, Martin C 3rd, Marini M, Hoang S, Mishina M, Ross WG, Sachedina MA, Friel CM, Mize J, Bickston SJ, Pizarro TT, Wei P, Cominelli F (2003) Expression, localization, and functional activity of TL1A, a novel Th1-polarizing cytokine in inflammatory bowel disease. J Immunol 171:4868-4874.

Bamias G, Mishina M, Nyce M, Ross WG, Kollias G, Rivera-Nieves J, Pizarro TT, Cominelli F (2006) Role of TL1A and its receptor DR3 in two models of chronic murine ileitis. Proc Natl Acad Sci U S A 103:8441-8446.

Bamias G, Siakavellas SI, Stamatelopoulos KS, Chryssochoou E, Papamichael C, Sfikakis PP (2008) Circulating levels of TNF-like cytokine 1A (TL1A) and its decoy receptor 3 (DcR3) in rheumatoid arthritis. Clin Immunol 129:249-255.

Baracchi F, Opp MR (2008) Sleep-wake behavior and responses to sleep deprivation of mice lacking both interleukin-1 beta receptor 1 and tumor necrosis factor-alpha receptor 1. Brain Behav Immun 22:982-993.

Bartles JR, Zheng L, Li A, Wierda A, Chen B (1998) Small espin: a third actin-bundling protein and potential forked protein ortholog in brush border microvilli. J Cell Biol 143:107-119.

Beattie EC, Stellwagen D, Morishita W, Bresnahan JC, Ha BK, Von Zastrow M, Beattie MS, Malenka RC (2002) Control of synaptic strength by glial TNFalpha. Science 295:2282-2285.
Bodmer JL, Burns K, Schneider P, Hofmann K, Steiner V, Thome M, Bornand T, Hahne M, Schröter M, Becker K, Wilson A, French LE, Browning JL, MacDonald HR, Tschopp J (1997) TRAMP, a novel apoptosis-mediating receptor with sequence homology to tumor necrosis factor receptor 1 and Fas(Apo-1/CD95). Immunity 6:79-88.

Borysenko CW, García-Palacios V, Griswold RD, Li Y, Iyer AK, Yaroslavskiy BB, Sharrow AC, Blair HC (2006) Death receptor-3 mediates apoptosis in human osteoblasts under narrowly regulated conditions. J Cell Physiol 209:1021-1028.

Bossen C, Ingold K, Tardivel A, Bodmer JL, Gaide O, Hertig S, Ambrose C, Tschopp J, Schneider P (2006) Interactions of tumor necrosis factor (TNF) and TNF receptor family members in the mouse and human. J Biol Chem 281:13964-13971.

Bull MJ, Williams AS, Mecklenburgh Z, Calder CJ, Twohig JP, Elford C, Evans BA, Rowley TF, Slebioda TJ, Taraban VY, Al-Shamkhani A, Wang EC (2008) The Death Receptor 3-TNF-like protein 1A pathway drives adverse bone pathology in inflammatory arthritis. J Exp Med 205: 2457-2464.

Carta M, Carlsson T, Muñoz A, Kirik D, Björklund A (2008) Serotonindopamine interaction in the induction and maintenance of L-DOPAinduced dyskinesias. Prog Brain Res 172:465-478.

Cassatella MA, Pereira-da-Silva G, Tinazzi I, Facchetti F, Scapini P, Calzetti F, Tamassia N, Wei P, Nardelli B, Roschke V, Vecchi A, Mantovani A, Bambara LM, Edwards SW, Carletto A (2007) Soluble TNF-like cytokine (TL1A) production by immune complexes stimulated monocytes in rheumatoid arthritis. J Immunol 178:7325-7333.

Catts VS, Al-Menhali N, Burne TH, Colditz MJ, Coulson EJ (2008) The p75 neurotrophin receptor regulates hippocampal neurogenesis and related behaviours. Eur J Neurosci 28:883-892.

Cenci MA, Lindgren HS (2007) Advances in understanding L-DOPAinduced dyskinesia. Curr Opin Neurobiol 17:665-671.

Chinnaiyan AM, O’Rourke K, Yu GL, Lyons RH, Garg M, Duan DR, Xing L, Gentz R, Ni J, Dixit VM (1996) Signal transduction by DR3, a death domain-containing receptor related to TNFR-1 and CD95. Science 274:990-992.

Costa RM, Lin SC, Sotnikova TD, Cyr M, Gainetdinov RR, Caron MG, Nicolelis MA (2006) Rapid alterations in corticostriatal ensemble coordination during acute dopamine-dependent motor dysfunction. Neuron 52:359-369.

Czeschik JC, Hagenacker T, Schäfers M, Büsselberg D (2008) TNF-alpha differentially modulates ion channels of nociceptive neurons. Neurosci Lett 434:293-298.

De Roo M, Klauser P, Muller D (2008) LTP promotes a selective long-term stabilization and clustering of dendritic spines. PLoS Biol 6:e219.

Diem R, Meyer R, Weishaupt JH, Bahr M (2001) Reduction of potassium currents and phosphatidylinositol 3-kinase-dependent AKT phosphorylation by tumor necrosis factor- $\alpha$ rescues axotomized retinal ganglion cells from retrograde cell death in vivo. J Neurosci 21:2058-2066.

Di Matteo V, Di Giovanni G, Pierucci M, Esposito E (2008) Serotonin control of central dopaminergic function: focus on in vivo microdialysis studies. Prog Brain Res 172:7-44.

Dubé L, Smith AD, Bolam JP (1988) Identification of synaptic terminals of thalamic or cortical origin in contact with distinct medium-size spiny neurons in the rat neostriatum. J Comp Neurol 267:455-471.

Dunnett SB, Carter RJ, Watts C, Torres EM, Mahal A, Mangiarini L, Bates G, Morton AJ (1998) Striatal transplantation in a transgenic mouse model of Huntington's disease. Exp Neurol 154:31-40.

Eby MT, Jasmin A, Kumar A, Sharma K, Chaudhary PM (2000) TAJ, a novel member of the tumor necrosis factor receptor family, activates the c-Jun $\mathrm{N}$-terminal kinase pathway and mediates caspase-independent cell death. J Biol Chem 275:15336-15342.

Fang L, Adkins B, Deyev V, Podack ER (2008) Essential role of TNF receptor superfamily 25 (TNFRSF25) in the development of allergic lung inflammation. J Exp Med 205:1037-1048.

Fernagut PO, Diguet E, Bioulac B, Tison F (2004) MPTP potentiates 3 -nitropropionic acid-induced striatal damage in mice: reference to striatonigral degeneration. Exp Neurol 185:47-62.

Fiacco TA, Agulhon C, McCarthy KD (2009) Sorting out astrocyte physiology from pharmacology. Annu Rev Pharmacol Toxicol 49:151-174.

Goldman-Rakic PS (1987) Circuitry of the frontal association cortex and its relevance to dementia. Arch Gerontol Geriatr 6:299-309. 
Grahn JA, Parkinson JA, Owen AM (2008) The cognitive functions of the caudate nucleus. Prog Neurobiol 86:141-155.

Graybiel AM (2005) The basal ganglia: learning new tricks and loving it. Curr Opin Neurobiol 15:638-644.

Groenewegen HJ (2003) The basal ganglia and motor control. Neural Plast 10:107-120.

Hamill CA, Michaelson JS, Hahm K, Burkly LC, Kessler JA (2007) Agedependent effects of TWEAK/Fn14 receptor activation on neural progenitor cells. J Neurosci Res 85:3535-3544.

Harrison DC, Roberts J, Campbell CA, Crook B, Davis R, Deen K, Meakin J, Michalovich D, Price J, Stammers M, Maycox PR (2000) TR3 death receptor expression in the normal and ischaemic brain. Neuroscience 96:147-160.

Harry GJ, Lefebvre d'Hellencourt C, McPherson CA, Funk JA, Aoyama M, Wine RN (2008) Tumor necrosis factor p55 and p75 receptors are involved in chemical-induced apoptosis of dentate granule neurons. J Neurochem 106:281-298.

Hayashi S, Taira A, Inoue G, Koshi T, Ito T, Yamashita M, Yamauchi K, Suzuki M, Takahashi K, Ohtori S (2008) TNF-alpha in nucleus pulposus induces sensory nerve growth: a study of the mechanism of discogenic low back pain using TNF-alpha-deficient mice. Spine 33:1542-1546.

Heuninckx S, Wenderoth N, Debaere F, Peeters R, Swinnen SP (2005) Neural basis of aging: the penetration of cognition into action control. J Neurosci 25:6787-6796.

Hou H, Obregon D, Lou D, Ehrhart J, Fernandez F, Silver A, Tan J (2008) Modulation of neuronal differentiation by CD40 isoforms. Biochem Biophys Res Commun 369:641-647.

Ishiguro A, Inagaki M, Kaga M (2007) Stereotypic circling behavior in mice with vestibular dysfunction: asymmetrical effects of intrastriatal microinjection of a dopamine agonist. Int J Neurosci 117:1049-1064.

Kannari K, Shen H, Arai A, Tomiyama M, Baba M (2006) Reuptake of L-DOPA-derived extracellular dopamine in the striatum with dopaminergic denervation via serotonin transporters. Neurosci Lett 402:62-65.

Kaptein A, Jansen M, Dilaver G, Kitson J, Dash L, Wang E, Owen MJ, Bodmer JL, Tschopp J, Farrow SN (2000) Studies on the interaction between TWEAK and the death receptor WSL-1/TRAMP (DR3). FEBS Lett 485:135-141.

Kelly CM, Precious SV, Penketh R, Amso N, Dunnett SB, Rosser AE (2007) Striatal graft projections are influenced by donor cell type and not the immunogenic background. Brain 130:1317-1329.

Kitson J, Raven T, Jiang YP, Goeddel DV, Giles KM, Pun KT, Grinham CJ, Brown R, Farrow SN (1996) A death-domain-containing receptor that mediates apoptosis. Nature 384:372-375.

Kojima T, Morikawa Y, Copeland NG, Gilbert DJ, Jenkins NA, Senba E, Kitamura T (2000) TROY, a newly identified member of the tumor necrosis factor receptor superfamily, exhibits a homology with Edar and is expressed in embryonic skin and hair follicles. J Biol Chem 275:20742-20747.

Kramer ER, Aron L, Ramakers GM, Seitz S, Zhuang X, Beyer K, Smidt MP, Klein R (2007) Absence of Ret signaling in mice causes progressive and late degeneration of the nigrostriatal system. PLoS Biol 5:e39.

Leng A, Mura A, Feldon J, Ferger B (2005) Tumor necrosis factor-alpha receptor ablation in a chronic MPTP mouse model of Parkinson's disease. Neurosci Lett 375:107-111.

Lesch KP, Zeng Y, Reif A, Gutknecht L (2003) Anxiety-related traits in mice with modified genes of the serotonergic pathway. Eur J Pharmacol 480:185-204.

Mackay F, Kalled SL (2002) TNF ligands and receptors in autoimmunity: an update. Curr Opin Immunol 14:783-790.

Marsters SA, Sheridan JP, Donahue CJ, Pitti RM, Gray CL, Goddard AD, Bauer KD, Ashkenazi A (1996) Apo-3, a new member of the tumor necrosis factor receptor family, contains a death domain and activates apoptosis and NF-kappa B. Curr Biol 6:1669-1676.

Mattson MP, Duan W, Chan SL, Cheng A, Haughey N, Gary DS, Guo Z, Lee J, Furukawa K (2002) Neuroprotective and neurorestorative signal transduction mechanisms in brain aging: modification by genes, diet and behavior. Neurobiol Aging 23:695-705.

Meylan F, Davidson TS, Kahle E, Kinder M, Acharya K, Jankovic D, Bundoc V, Hodges M, Shevach EM, Keane-Myers A, Wang EC, Siegel RM (2008) The TNF-family receptor DR3 is essential for diverse T cell-mediated inflammatory diseases. Immunity 29:79-89.

Migone TS, Zhang J, Luo X, Zhuang L, Chen C, Hu B, Hong JS, Perry JW,
Chen SF, Zhou JX, Cho YH, Ullrich S, Kanakaraj P, Carrell J, Boyd E, Olsen HS, Hu G, Pukac L, Liu D, Ni J, et al. (2002) TL1A is a TNF-like ligand for DR3 and TR6/DcR3 and functions as a T cell costimulator. Immunity 16:479-492.

Nave KA, Trapp BD (2008) Axon-glial signaling and the glial support of axon function. Annu Rev Neurosci 31:535-561.

Newman SJ, Bond B, Crook B, Darker J, Edge C, Maycox PR (2000) Neuron-specific localisation of the TR3 death receptor in Alzheimer's disease. Brain Res 857:131-140.

Nieoullon A, Coquerel A (2003) Dopamine: a key regulator to adapt action, emotion, motivation and cognition. Curr Opin Neurol 16 [Suppl 2]:S3-S9.

Ogoshi F, Yin HZ, Kuppumbatti Y, Song B, Amindari S, Weiss JH (2005) Tumor necrosis-factor-alpha (TNF-alpha) induces rapid insertion of Ca2 + permeable alpha-amino-3-hydroxyl-5-methyl-4-isoxazole-propionate (AMPA)/kainate $(\mathrm{Ca}-\mathrm{A} / \mathrm{K})$ channels in a subset of hippocampal pyramidal neurons. Exp Neurol 193:384-393.

O’Keeffe GW, Gutierrez H, Pandolfi PP, Riccardi C, Davies AM (2008) NGF-promoted axon growth and target innervation requires GITRLGITR signaling. Nat Neurosci 11:135-142.

Osawa K, Takami N, Shiozawa K, Hashiramoto A, Shiozawa S (2004) Death receptor 3 (DR3) gene duplication in a chromosome region 1p36.3: gene duplication is more prevalent in rheumatoid arthritis. Genes Immun 5:439-443.

O’Sullivan M, Jones DK, Summers PE, Morris RG, Williams SC, Markus HS (2001) Evidence for cortical "disconnection" as a mechanism of agerelated cognitive decline. Neurology 57:632-638.

Ozaktay AC, Kallakuri S, Takebayashi T, Cavanaugh JM, Asik I, DeLeo JA, Weinstein JN (2006) Effects of interleukin-1 beta, interleukin-6, and tumor necrosis factor on sensitivity of dorsal root ganglion and peripheral receptive fields in rats. Eur Spine J 15:1529-1537.

Palmiter RD (2008) Dopamine signaling in the dorsal striatum is essential for motivated behaviors: lessons from dopamine-deficient mice. Ann N Y Acad Sci 1129:35-46.

Pan G, Bauer JH, Haridas V, Wang S, Liu D, Yu G, Vincenz C, Aggarwal BB, Ni J, Dixit VM (1998) Identification and functional characterization of DR6, a novel death domain-containing TNF receptor. FEBS Lett 431:351-356.

Papadakis KA, Zhu D, Prehn JL, Landers C, Avanesyan A, Lafkas G, Targan SR (2005) Dominant role for TL1A/DR3 pathway in IL-12 plus IL-18induced IFN-gamma production by peripheral blood and mucosal CCR9+ T lymphocytes. J Immunol 174:4985-4990.

Pappu BP, Borodovsky A, Zheng TS, Yang X, Wu P, Dong X, Weng S, Browning B, Scott ML, Ma L, Su L, Tian Q, Schneider P, Flavell RA, Dong C, Burkly LC (2008) TL1A-DR3 interaction regulates Th17 cell function and Th17-mediated autoimmune disease. J Exp Med 205:1049-1062.

Pineda JR, Canals JM, Bosch M, Adell A, Mengod G, Artigas F, Ernfors P, Alberch J (2005) Brain-derived neurotrophic factor modulates dopaminergic deficits in a transgenic mouse model of Huntington's disease. J Neurochem 93:1057-1068.

Pispa J, Mikkola ML, Mustonen T, Thesleff I (2003) Ectodysplasin, Edar and TNFRSF19 are expressed in complementary and overlapping patterns during mouse embryogenesis. Gene Expr Patterns 3:675-679.

Prehn JL, Thomas LS, Landers CJ, Yu QT, Michelsen KS, Targan SR (2007) The $\mathrm{T}$ cell costimulator TL1A is induced by FcgammaR signaling in human monocytes and dendritic cells. J Immunol 178:4033-4038.

Quintana A, Molinero A, Florit S, Manso Y, Comes G, Carrasco J, Giralt M, Borup R, Nielsen FC, Campbell IL, Penkowa M, Hidalgo J (2007) Diverging mechanisms for TNF-alpha receptors in normal mouse brains and in functional recovery after injury: from gene to behavior. J Neurosci Res 85:2668-2685.

Rakic P (1988) Specification of cerebral cortical areas. Science 241:170-176.

Ross FM, Allan SM, Rothwell NJ, Verkhratsky A (2003) A dual role for interleukin-1 in LTP in mouse hippocampal slices. J Neuroimmunol 144:61-67.

Sawada M, Kondo N, Suzumura A, Marunouchi T (1989) Production of tumor necrosis factor-alpha by microglia and astrocytes in culture. Brain Res 491:394-397.

Schafers M, Sorkin L (2008) Effect of cytokines on neuronal excitability. Neurosci Lett 437:188-193.

Screaton GR, Xu XN, Olsen AL, Cowper AE, Tan R, McMichael AJ, Bell JI (1997) LARD: a new lymphoid-specific death domain containing recep- 
tor regulated by alternative pre-mRNA splicing. Proc Natl Acad Sci U S A 94:4615-4619.

Shao Z, Browning JL, Lee X, Scott ML, Shulga-Morskaya S, Allaire N, Thill G, Levesque M, Sah D, McCoy JM, Murray B, Jung V, Pepinsky RB, Mi S (2005) TAJ/TROY, an orphan TNF receptor family member, binds Nogo-66 receptor 1 and regulates axonal regeneration. Neuron 45: 353-359.

Shin DH, Lee E, Kim HJ, Kim S, Cho SS, Chang KY, Lee WJ (2002) Fas ligand mRNA expression in the mouse central nervous system. J Neuroimmunol 123:50-57.

Simen BB, Duman CH, Simen AA, Duman RS (2006) TNFalpha signaling in depression and anxiety: behavioral consequences of individual receptor targeting. Biol Psychiatry 59:775-785.

Smith Y, Bennett BD, Bolam JP, Parent A, Sadikot AF (1994) Synaptic relationships between dopaminergic afferents and cortical or thalamic input in the sensorimotor territory of the striatum in monkey. J Comp Neurol 344:1-19.

Stellwagen D, Malenka RC (2006) Synaptic scaling mediated by glial TNFalpha. Nature 440:1054-1059.

Stellwagen D, Beattie EC, Seo JY, Malenka RC (2005) Differential regulation of AMPA receptor and GABA receptor trafficking by tumor necrosis factor- $\alpha$. J Neurosci 25:3219-3228.

Takedatsu H, Michelsen KS, Wei B, Landers CJ, Thomas LS, Dhall D, Braun J, Targan SR (2008) TL1A (TNFSF15) regulates the development of chronic colitis by modulating both T-helper 1 and T-helper 17 activation. Gastroenterology 135:552-567.

Tan J, Town T, Mori T, Obregon D, Wu Y, DelleDonne A, Rojiani A, Crawford F, Flavell RA, Mullan M (2002) CD40 is expressed and functional on neuronal cells. EMBO J 21:643-652.

Torres EM, Monville C, Gates MA, Bagga V, Dunnett SB (2007) Improved survival of young donor age dopamine grafts in a rat model of Parkinson's disease. Neuroscience 146:1606-1617.

Truong L, Allbutt H, Kassiou M, Henderson JM (2006) Developing a preclinical model of Parkinson's disease: a study of behaviour in rats with graded 6-OHDA lesions. Behav Brain Res 169:1-9.

Wang EC, Thern A, Denzel A, Kitson J, Farrow SN, Owen MJ (2001a) DR3 regulates negative selection during thymocyte development. Mol Cell Biol 21:3451-3461.
Wang EC, Kitson J, Thern A, Williamson J, Farrow SN, Owen MJ (2001b) Genomic structure, expression, and chromosome mapping of the mouse homologue for the WSL-1 (DR3, Apo3, TRAMP, LARD, TR3, TNFRSF12) gene. Immunogenetics 53:59-63.

Yamada H, Aimi Y, Nagatsu I, Taki K, Kudo M, Arai R (2007) Immunohistochemical detection of L-DOPA-derived dopamine within serotonergic fibers in the striatum and the substantia nigra pars reticulata in Parkinsonian model rats. Neurosci Res 59:1-7.

Yan M, Xia C, Cheng C, Shao X, Niu S, Liu H, Shen A (2007) The role of TNF-alpha and its receptors in the production of Src-suppressed C kinase substrate by rat primary type-2 astrocytes. Brain Res 1184:28-37.

Yan Q, Johnson EM Jr (1988) An immunohistochemical study of the nerve growth factor receptor in developing rats. J Neurosci 8:3481-3498.

Yang CR, Hsieh SL, Teng CM, Ho FM, Su WL, Lin WW (2004) Soluble decoy receptor 3 induces angiogenesis by neutralization of TL1A, a cytokine belonging to tumor necrosis factor superfamily and exhibiting angiostatic action. Cancer Res 64:1122-1129.

Yang DS, Kumar A, Stavrides P, Peterson J, Peterhoff CM, Pawlik M, Levy E, Cataldo AM, Nixon RA (2008) Neuronal apoptosis and autophagy cross talk in aging PS/APP mice, a model of Alzheimer's disease. Am J Pathol 173:665-681.

Yankner BA, Lu T, Loerch P (2008) The aging brain. Annu Rev Pathol 3:41-66.

Yao WD, Spealman RD, Zhang J (2008) Dopaminergic signaling in dendritic spines. Biochem Pharmacol 75:2055-2069.

Zheng L, Sekerková G, Vranich K, Tilney LG, Mugnaini E, Bartles JR (2000) The deaf jerker mouse has a mutation in the gene encoding the espin actin-bundling proteins of hair cell stereocilia and lacks espins. Cell 102:377-385.

Zhou QY, Palmiter RD (1995) Dopamine-deficient mice are severely hypoactive, adipsic, and aphagic. Cell 83:1197-1209.

Zuliani C, Kleber S, Klussmann S, Wenger T, Kenzelmann M, Schreglmann N, Martinez A, del Rio JA, Soriano E, Vodrazka P, Kuner R, Groene HJ, Herr I, Krammer PH, Martin-Villalba A (2006) Control of neuronal branching by the death receptor CD95 (Fas/Apo-1). Cell Death Differ 13:31-40. 